\title{
Review Article on Impact of ATM Service on Customer Satisfaction
}

\author{
Benyam Tadesse* \\ Department of Agricultural Economics, Mizan-Tepi University, Ethiopia
}

Submission: April 23, 2018; Published: May 17, 2018

*Corresponding author: Benyam Tadesse, Department of Agricultural Economics, Mizan-Tepi University, Ethiopia, Tel: +251935938317;

Email: tadessebenyam7@gmail.com

Keywords: Customer satisfaction; Banking industry; ATM; Credit card; Debit card; Internet banking; Mobile banking; Electronic fund transfer; Electronic clearing services; Financial transaction; Local currency; Independent variables; Dependent variable; ATM banking; ATM cards; ATM stations; ATM issues.

Abbreviations: ATM: Automated Teller Machine; PC: Personal Computer; PDA: Personal Digital Assistant; EBH: Extended Business Hours; EFT: Electronic Fund Transfer

\section{Introduction}

\section{Background of the study}

In banking industry, e-services are revolutionizing the way business is conducted. Electronic based business models are replacing conventional banking system and most banks are rethinking business process designs and customer relationship management strategies. It is also known as e-banking, online banking which provides various alternative e-channels to using banking services i.e. ATM, credit card, debit card, internet banking, mobile banking, electronic fund transfer, electronic clearing services etc. however, as per e-banking scenario ATM and mobile banking are most acknowledged than other e-channels [1].

Automated Teller Machine (ATM) refers to a machine that acts as a bank teller by receiving and issuing money to and from the ATM account holders/users. ATM means neither "avoids traveling with money" nor "any time money," but certainly implies both. ATM cards are fast replacing confounding withdrawal forms as a convenient way of getting your money from banks. In a way, they are rewriting the rules of financial transaction. A smart person no longer needs to carry a walletfull of paper money; rather, what he/she needs to do is to fish out an Automated Teller Machine (ATM) card from his/ her pocket, insert it in the slot of the machine, punch in a few details and go home with hard cash [1].

The history of ATM can be traced back to the 1960s, when John Shepherd-Barron who was managing director of De La Rue Instruments invented the first ATM machine. That machine used by Barclays Bank (Barclays Bank in Enfield Town in North London, United Kingdom) on 27 June 1967 [1].

ATM is designed to perform the most important function of bank. The plastic card is replacing cheque, personal attendance of the customer, banking hour's restrictions and paper based verification. ATMs are used as spring board for Electronic Fund Transfer. ATM itself can provide information about customers account and also receive instructions from customers-ATM cardholders. An ATM is an Electronic Fund Transfer terminal capable of handling cash deposits, transfer between accounts, balance enquiries, cash withdrawals and pay bills [2].

In many parts of the world the majority of bank customers regularly use Automatic Teller Machines (ATMs) and today's western youth have not known a world without them. For them, the prevailing Perception of a cash machine is that of a tool providing a familiar functionality of basic financial information and dispensing cash. The technology is hidden from sight; the computer is invisible. It has taken approximately 30 years to establish ATMs as ubiquitous examples of public walkupand-use devices. The adoption has not been straightforward, requiring trust in the technology and willingness to modify behavioral strategies in the very sensitive domain of personal finance. Financial institutions have played a major, sometime coercive, role in encouraging ATM adoption. The ATM flourishes within societies where time is precious and money readily available. This culture is composed of individuals, who have personal bank accounts and access to a wide range of technology. For these individuals, ATMs are 
convenient and reliable everyday artifacts: push a few buttons and get the money. As ATMs cross-new borders and pervade different cultures, it is imperative to understand the role of cultural characteristics on people's Perception of, attitudes towards, and action on, the machine. This understanding is instrumental in facilitating technology uptake and improving design localization, or the process of infusing a specific cultural context into products designed for different cultures [3].

In Africa, ATMs are being introduced for the first time and we must understand the new users who live within a culture, which may bring new factors into the adoption curve. It concentrates on urban Africa but the approach can be generalized to cover other public (and personal) technologies, as well as other developing markets. African Banking industry is witnessing an unprecedented competition. To stay ahead, banks are coming up with plethora of services to lure customers. Services like 24hour banking, service at door step, telephone banking, internet banking, Extended Business Hours (EBH), speedy processing are only a few to mention. Greater part of today's bank transactions take place somewhere else other than in branch premises [1].

Though, the aim of these services is to satisfy customers, there is a need to understand customer awareness, Perception and importantly the level of satisfaction. Efforts are directed to attract and retain customers by offering them a basket of tailor made schemes supported by a state of the art distribution system (the ATMs). The whole exercise is helping banks to serve their customers fast and avoid human intervention totally. And for the customers, ATMs offer hassle-free cash withdrawal. No more fighting with the bank's teller for change and fresh notes. The total cash movement through ATMs in Africa is already between Millions of shillings (local currency) every year. In future, things are going to be even more different and challenging. The ATM has become a medium for non-cash transactions such as payment of bills, insurance payments, printing of statements or even accessing the internet [1].

Automated teller machine (ATM) banking is a popular access channel to banking products and services behind branch banking. Banks have been offering more access points to newer ATM technologies that are faster, secure and with a wider range of services that include cash depositing to achieve competitive advantage through the ATM banking. To retain bank profitability, expanding the base of satisfied customers is of essence. As such the concept of customer satisfaction and what makes customers satisfied is an area of frequent market studies. Knowing the factors that influence customers' satisfaction with ATM banking is of significance when it comes to deployment of ATM technologies.

\section{Concept of customer satisfaction}

Mwatsika [4] define customer satisfaction as a mental state which results from customers' comparison of expectations prior to a purchase with performance after a purchase [5]. Halstead et al (1994) states that customer satisfaction is a transaction specific effective response from customers' comparison of product performance to some pre-purchase standard. ATM banking customers have expectations of their banks' ATM banking services against which each service encounter enhances comparison of ATM banking performance to the expectations. The comparison is conducted after the immediate usage of ATM banking services or over time of ATM banking usage.

Customer satisfaction with ATM banking is therefore the feeling developed from an evaluation of the ATM banking use experience whether the ATM banking performed relatively well or poorly against expectations. Churchill GA \& Surprenant [5] defines customer satisfaction as the overall post purchase or usage evaluation. Look at customer satisfaction as a summation of satisfaction with various attributes of a product which alludes to the fact that satisfaction with ATM banking will come from the satisfaction with the performance of its attributes. The evaluative judgment about satisfaction with ATM banking is therefore conceived to fall somewhere on a bipolar continuum where at the lower end it signifies low levels of satisfaction (expectations exceed performance perceptions) and at the higher end it signifies a higher level of satisfaction (performance perceptions exceed expectations). This evaluative judgment occurs at a particular time based on usage experience of ATM banking which occurred at a particular time or on accumulated experience of ATM banking.

The concept of customer satisfaction has in general become of particular importance because various empirical researchers have shown that it is an antecedent of customer retention [6] that increases market share [6] the corporate image of the firm and long term profitability. Banks would expect to retain and/ or expand customer base of ATM banking, holding other factors constant, if the ATM banking performance meets customers' expectations or surpasses expectations.

\section{Electronic banking}

Electronic banking is a form of banking business that provides banking services to individuals and corporate entities, which are offered and performed with the use of computer networks and telecommunications media (electronic support). Electronic banking includes conducting banking activities using information and telecommunication technologies. E-banking now becomes a virtual banking counter that the individual and corporate customer to carry out the regular banking activities [6]. The term electronic banking is used to describe the provision of information or services by a bank to its customers, via a computer or communication technologies [6], conducting banking activities using information and telecommunication technologies [7], a group of electronic system or equipment called electronic fund transfer system, 
which involves the application of advance computer and communication technologies for effecting payment systems that enable financial institution customers, individuals or businesses, to access accounts, transact business, or obtain information on financial products and services through a public or private network, including the Internet $[6,7]$. Electronic banking can be defined as the provision of information or services by a bank to its customers, describes it as an electronic connection between bank and customer in order to prepare, manage and control financial transactions [7]. Daniel [8] described electronic banking as the provision of banking services to customers through Internet technology. E-banking is also defined as the automated delivery of new and traditional banking products and services directly to customers through electronic, interactive communication channels $[6,9]$. Furthermore, e-banking is defined as a contemporary business model that involves the use of modern information and telecommunication technologies in carrying out banking transactions from home, the office, or from business trip, 24 hours a day, 365 days in a year [9].

For customers, e-banking provides current information, 24-hours-a-day access to banking services (Hamid, 2012; [9]. Customers access e-banking services using an intelligent electronic device, such as a Personal Computer (PC), Personal Digital Assistant (PDA), Automated Teller Machine (ATM), internet [6]. Electronic distribution channels provide alternatives for faster delivery of banking services to a wider range of customers [10].

Electronic banking is an attempt to merge a number of different technologies (electronic cash, ATM, POS/EFTPOS terminals, credit cards, home banking, online banking, Internet banking, mobile banking, etc.), each of them evolved in a different direction and in a different way, with the aim of providing various banking products and services to end-users [11]. Telephone banking provides services such as account balances, instruction to issue bank cheques, account payments. While ATM, the most frequently used electronic distribution channel, allows customers to perform their main banking transactions, such as deposits and withdrawals, 24hours a day. Furthermore, internet banking allows consumers to check account balances, conduct credit card payments/transfers, transfer funds and account payments.

E-banking services have provided numerous benefits for both banks and customers. The first benefit for banks offering electronic banking services is better branding and improved responsiveness to the market [1]. Tillya [1] observed that the main advantage of e-banking is a new distribution channel providing improved services to customers, as well as the use of electronic commerce strategies. The development of e-banking has greatly helped banks to minimize their overheads, charges and service costs. Many routine services and tasks have now been fully computerized and are quicker and more efficient.

\section{Measuring customer satisfaction}

There are three dominant paradigms to the measurement of customer satisfaction $[12,13]$. The Importance-performance approach [14] proposes that customer satisfaction with a product or service is a composite of (1) the perceived importance of a range of the product/service attributes or benefits and (2) the customers' beliefs about the degree to which the product or service has each attribute. When the perceived performance of the product or service is measured, the importance scores are weighed against the performance scores on each attribute to determine the product or service strengths or weaknesses.

The importance-performance approach enables the researcher to analyse whether the product or service has or performs in attributes considered important by the customer (user). Thereby if the product/service performs in attributes considered important by customers (users) then the product/ service has more chances of satisfying customers (users) and subsequently retaining them for repeat purchases and business growth. This is a very interesting conception of customer satisfaction that has received considerable empirical support in literature according to Sheppard.

The second measurementapproach to customer satisfaction is the Expectations-performance disconfirmation by Portela M \& Thanassoulis [13]. This approach is based on the proposition that customers evaluate or measure their satisfaction with a product/service by comparing preconception expectations with post-consumption perceptions (performance). This is the basis of the SERVQUAL (Service Quality) measurement model by Parasuraman et al. [15].

The SERVQUAL model allows customers to rate the product/service on a set of general attributes presented on a Likert scale to measure their expectations of and their perceptions of the performance of product/service attributes to measure customer satisfaction. Performance only by Cronin JJ \& Taylor [12] is the third approach to measurement of customer satisfaction. This approach challenges the previous two approaches by proposing that customer satisfaction is affected by the customers' perceptions of the performance of the product/service only. This approach ignores the importance [14] and customers' expectations [13] in the measurement of customer satisfaction. Cronin JJ \& Taylor [12] conceptualization of this measurement approach is the basis of SERVPERF (Service performance) model which is a Likert scale where customers measure their perceived performance only of the product/service general attributes to determine their satisfaction with the product/service. The continuing debate in literature for the merits of SERVQUAL and SERVPERF and vice versa, support SERVPERF, the performance based paradigm over SERVPERF, the disconfirmation based paradigm.

However, both measurement approaches, SERVQUAL and SERVPERF, subscribe to the conceptualization that the product/ 
service is a bundle of attributes (features) whose performance quality determines the level of customers' satisfaction with the product/service. The customers' satisfaction comes from the overall judgment about the product/service superiority by comparing attributes' importance with performance [14] or comparing expectations of attributes with performance [13] or performance of attributes only [12].

\section{ATM Banking Attributes}

Marketing literature defines a product/service as bundle of features (attributes) [13] that bears ability to satisfy implicit or explicit needs/wants of customers. Service quality is therefore a measure of how well a product/service is delivered to meet the expectations of customers [13].

Literature thus asserts service quality as an antecedent to customer satisfaction [3]. Similarly, ATM banking is a product/ service that has attributes/features that meet implicit and/ or explicit needs of bank customers. To achieve customer satisfaction the attributes have to deliver service quality to customers' expected threshold. Therefore before customer satisfaction is delivered through ATM banking, managers ought to understand the features/attributes of ATM banking that provide service quality because these are the factors that influence performance superiority [13] to influence customer satisfaction [16].

Various empirical studies Al-Hawari M [11], Lovelock CH [17], Moutinho [18], Yavas U [19]; and Davies F [20]; identified ATM banking attributes that were adopted by this study. These attributes include number of ATMs per ATM station; issuance of clean notes; readable slips; accessibility to a wide range of banking services via ATMs, appearance of corporate branding on ATMs, cleanliness of ATMs and ATM stations; ease of application process for ATM cards; privacy when using ATMs; advice on ATM usage and ATM security; employee accessibility to solve ATM problems; convenient location of ATMs; ATM fees; security at ATM stations; bank employee friendliness when assisting on ATM issues; quick replacement of lost cards; fast return of swallowed cards; employee speed in responding to ATM problems; employee effectiveness in solving ATM problems; waiting times at ATMs; ATMs not out of order; accuracy of ATM transactions; cash availability in ATMs; speed of ATM transactions and user friendliness of ATM systems.

There were a total of 25 ATM attributes adopted from the empirical studies. These ATM banking attributes fall within the five dimensions of service quality [15] that include: tangibles, reliability, responsiveness, assurance and empathy. Tangibles are the physical facilities, equipment as well as appearance of personnel; reliability is the ability to perform the promised service dependably and accurately; responsiveness is willingness to help customers and offer prompt service; assurance is knowledge and courtesy of employees and their ability to inspire trust and confidence; and empathy is caring, individualized attention the firm provides its customers [21].

The study adopted 25 attributes of ATM banking from empirical studies falling into the five dimensions of service quality for the analysis of the factors that affect customers' satisfaction with ATM banking and will be operationalized through a multiple scale performance measurement instrument.

\section{Research Model}

The literature review informed the study that a product/ service such as ATM banking is a bundle of features/attributes (Stanton et al, 1991) that bears the ability to satisfy implicit or explicit needs/wants of customers. These features/attributes are categorized into five dimensions; the tangibles, reliability, responsiveness, assurance and empathy [15]. Service quality refers to how well these product/service features/ attributes deliver to meet the expectations of customers about the product/service. Therefore the performance of the features/attributes of products/services in each service quality dimension determines customers' satisfaction with the product/service as depicted in This therefore formed the research model in conceptualizing, categorizing and analyzing the performance of factors that influence customers' satisfaction with ATM banking.

There were 25 attributes/features of ATM banking that were adopted from empirical studies [1, 11]; [17-20] and were classified into the five dimensions of product/service attributes/features as follows: the tangibles aspect comprised of (1) number of ATMs per ATM station, (2) convenient location, (3) corporate brand appearance on ATMs, (4) readable ATM slips, (5) issuing of clean notes and (6) cleanliness of ATMs and ATM stations [21-26].

The reliability aspect comprised:

1) Range of services at ATMs,

2) Accuracy of ATM transactions,

3) Speed of ATMs,

4) ATMs not out of order,

5) ATM system usability and

6) Ease of access to ATMs.

The responsiveness aspect comprised:

1) Cash availability in ATMs,

2) Quick replacement of lost ATM cards,

3) Waiting times at ATMs,

4) Fast return of swallowed ATM cards,

5) Employee speed in dealing with ATM problems, and 
6) Employee effectiveness in solving ATM problems [2730].

Assurance dimension comprised:

1) Privacy at ATMs,

2) ATM usage and ATM security advice, and

3) Security at ATM stations and finally empathy dimension comprised:
a. Employee friendliness.
b. ATM fees.
c. Ease of ATM card application process.
d. Employee accessibility to solve ATM issues [31-33].

\section{Conclusion}

Many literatures predicted that all 25ATM banking attributes that were proved to provide a perfect model for predicting customers' satisfaction with ATM banking, the performance of ATM banking attributes (independent variables) and customers' satisfaction (dependent variable) identifies ATM fees charged, ATMs not out of order, cleanliness of ATMs, accuracy of ATM transactions, ease of access to ATMs, readable slips, convenient location, employee accessibility to solve ATM problems, privacy at ATM stations, employee speed in solving ATM issues, ease of application process for ATM cards and cash availability in ATMs as the key factors that influence customers' satisfaction with ATM banking.

\section{References}

1. Tillya JJ (2013) A Dissertation submitted in Partial/Fulfilment of the Requirements for the award of Master's Degree of Science in Accounting and Finance of Mzumbe University. Mzumbe, Tanzania.

2. Hood J (1979) Demographics of ATMs, Banker's Magazine. Banker's Magazine 68-71.

3. Anderson EA, Sullivan M, Anderson (1993) The Antecedents and Consequences of Customer Satisfaction for Firms. Marketing Science 12(2): $125-143$

4. Mwatsika C (2016) Factors Influencing Customer Satisfaction with ATM Banking. International Journal of Academic Research in Business and Social Sciences 6(2).

5. Churchill GA, Surprenant C (1982) An investigation into the determinants of customer satisfaction. Journal of Marketing Research 19(4): 491-504.

6. Goi CL (2005) E-Banking in Malaysia: Opportunity and Challenges. Journal of Internet Banking and Commerce 10(3).

7. Karjaluoto H (2002) Electronic Banking in Finland, Consumer Beliefs, Attitudes, Intentions, and Behaviors. Jyvaskyla Studies in Business and Economics 18: 91-118.

8. Daniel E (1999) Provision of electronic banking in the UK and the Republic of Ireland. International Journal of Bank Marketing 17(2): 72-83.

9. Rahimuddin M, Bukhari SA (2010) Banking System in Pakistan. Blekinge Institute of Technology, Ronneby, Sweden.
10. Hughes T (2001) Market orientation and the response of UK financial services companies to changes in Market conditions as a result e-commerce. International Journal of Bank Marketing 19(6): 222-231.

11. Al-Hawari M, Ward T (2006) The effect of automated service quality on bank financial performance and the mediating role of customer retention. Journal of Financial Service Marketing 10(3): 228-243.

12. Cronin JJ, Taylor SA (1992) Measuring service quality: A reexamination and extension 56(3): 55-68.

13. Portela M, Thanassoulis E (2005) Profitability of a sample of Portuguese bank branches and its decomposition into technical and allocative components. European Journal of Operational Research 162(3): 850866.

14. Fishbein M, Ajzen I (1975) Belief, attitude, intention and behavior: An introduction to theory and research. Addison-Wesley, Reading, Massachusetts.

15. Parasuraman A, Valarie AZ, Leonard LB (1985) A conceptual model of service quality and implications for future research. Journal of Marketing 49(4): 41-50.

16. Swan JE, Combs LJ (1976) Product performance and consumer satisfaction: A new concept. Journal of Marketing 40(2): 25-33.

17. Lovelock CH (2000) Functional integration in service: understanding the links between marketing, operations, and human resources. In Swartz TA and Iacobucci D (Eds.),

18. Moutinho L, Brownlie DT (1989) Customer satisfaction with bank services: a multidimensional space analysis. International Journal of Bank Marketing 7(5): 23-27.

19. Yavas U (2004) Relationship between service quality and behavioural outcomes: A study of private bank customers in Germany. The International Journal of Bank Marketing 22(2): 144-157.

20. Davies F, Moutinho L, Curry B (1996) ATM users attitudes: A neural network analysis. Marketing Intelligence \& Planning 14(2): 26-32.

21. Sachdev SB, Verma HV (2004) Relative importance of service quality dimensions: A multi sectoral study. Journal of Services Research 4(1).

22. Baker J (2001) Evaluating the impact of development projects on poverty: A handbook for parishioners. Washington, D.C.

23. Becker S, Caliendo M (2007) Observational Studies (Vol. 7).

24. Becker S, Ichino A (2002) Estimation of Average Treatment Effects Based on Propensity Scores. The Stata Journal 2(4): 358-377.

25. Caliendo M, Sabine K (2008) Some practical guidance for the implementation of propensity score matching. Journal of Economic Surveys 22(1): 31-72.

26. Dehejia R, Wahba S (2002) Propensity Score Matching Methods for Non-Experimental Causal Studies: The Review of Economics and Statistics 84(1): 151-161.

27. Karlan D, Godberg N (2006) The Impact of Microfinance: A Review of Methodological Issues".

28. Khan (2010) Empirical Study of Automated Teller Machine Service Quality and Customer Satisfaction in Pakistani Banks. European Journal of Social Sciences 13(3): 333-344.

29. Mols N (2000) The internet and service marketing-the case of Danish retail banking. Internet Research: Electronic Networking Applications and Policy 10(1): 7-18.

30. Rosenbaum P, Donald BR (1983) The Central Role of the Propensity Score in Observational Studies for Casual Effect. Biomertica 70(1): 4155. 
31. Rosenbaum PR (2002) Observational Studies. (2 ${ }^{\text {nd }}$ edn.), New York Springer.

32. Sintayehu Y, Duressa D (2015) The impacts of e-banking services on customer satisfaction: the case of selected commercial banks in a thesis submitted to add is Ababa university in pa.

This work is licensed under Creative Commons Attribution 4.0 License
33. Yared (2016) The Effect of Automatic Teller Machine Service Quality on Customer Satisfaction: The Case of Commercial Bank of Ethiopia in Hawassa City. Journal of Engineering and Economic Development 3: 1-13.

\section{Your next submission with Juniper Publishers will reach you the below assets}

- Quality Editorial service

- Swift Peer Review

- Reprints availability

- E-prints Service

- Manuscript Podcast for convenient understanding

- Global attainment for your research

- Manuscript accessibility in different formats ( Pdf, E-pub, Full Text, Audio)

- Unceasing customer service

Track the below URL for one-step submission https://juniperpublishers.com/online-submission.php 